\title{
Проблеми пізньої діагностики первинного гіперпаратиреозу
}

\begin{abstract}
Мета роботи: вивчити своєчасність і якість діагностики первинного гіперпаратиреозу (ПГПТ) у регіоні, визначити недоліки та розробити заходи покращення діагностичного алгоритму.

Матеріали і методи. Проведено ретроспективний аналіз медичної документації 64 пацієнтів, прооперованих на базі клінічної лікарні Кривого Рогу з приводу ПГПТ. Проаналізовано анамнез та клінічні прояви захворювання, результати додаткових обстежень (УЗД, лабораторні дослідження крові і сечі, рентгенологічні данні кісткового каркасу), результати хірургічного лікування.

Результати досліджень та їх обговорення. У роботі представлено ретроспективний аналіз ефективності діагностики у 64 пацієнтів оперованих з приводу первинного гіперпаратиреозу. У 32,9 \% пацієнтів із патологією щитоподібної залози (ЩЗ) виявлено малосимптомні або безсимптомні форми ПГПТ. У 43 (67,1 \%) пацієнтів із вісцеропатичними клінічними проявами ПГПТ його наявність встановлено при додатковому цілеспрямованому обстеженні, яке частіше проводилось у стаціонарних відділеннях клінічної лікарні при їх госпіталізації з приводу ускладнень захворювання. Хірургічне лікування ПГПТ у більшості випадків виконують при його маніфестних формах, коли формуються інвалідизуючі ускладнення. Найчастіше маніфестними проявами ПГПТ є змішані форми з перевагою уражень кісткового каркасу та нирок. Наведено клінічні випадки пацієнтів із запізнілою діагностикою маніфестних форм ПГПТ. Причиною такого стану є низький рівень обізнаності лікарів первинної ланки та суміжних спеціальностей в питаннях діагностики ПГПт.
\end{abstract}

Ключові слова: первинний гіперпаратиреоз; маніфестна форма; недоліки діагностики.

Постановка проблеми і аналіз останніх досліджень та публікацій. Первинний гіперпаратиреоз (ПГПТ) - захворювання пов'язане з гіперпродукцією паратгормону на фоні патологічних змін у прищитоподібних залозах. Патофізіологічною основою розвитку захворювання є порушення кальцієво-фосфорного гомеостазу організму людини. Незважаючи на прогрес у вивченні гіперпаратиреозу, вказане захворювання залишається актуальної проблемою ендокринної хірургії. За розповсюдженням серед ендокринної патології ПГПТ займає третє місце після цукрового діабету та захворювань щитоподібної залози з частотою виявлення 1:500 - 1:1000 [1, 2,4]. За даними більшості дослідників, у США і країнах Європи ПГПТ діагностують у 0,05-0,1 \% амбулаторних чи стаціонарних хворих, частота гіперкальціємії серед яких складає 0,3 \% [3].

Проблемним питанням первинного гіперпаратиреозу залишається своєчасне виявлення захворювання, яке має різноманітні клінічні прояви. За провідними клінічними проявами і патологічними порушеннями виділяють кісткову, вісцеропатичну (ниркову, абдомінальну, психоневрологічну, судинну) і змішану форми ПГПТ; за ступенем вираження клінічних проявів: маніфестну, малосимптомну та безсимптомну форми [2, 4, 7]. У діагностиці ПГПТ основними є лабораторні і променеві методи (визначення рівнів кальцію, фосфору, паратгормону, 25(OH)D ${ }_{3}$ УЗД, СКТ $з$ технецієм) $[2,4,5]$. Незважаючи на сьогоденну доступність вказаних методів діагностики, відсоток виявлення
ПГПТ на його ранніх проявах залишається на низькому рівні. Несвоєчасна діагностика ПГПТ є причиною розвитку занедбаних форм захворювання 3 тяжкими ускладненнями, що часто призводить до інвалідизації пацієнтів і летальних наслідків $[6,8]$.

Мета роботи: вивчити своєчасність і якість діагностики первинного гіперпаратиреозу в регіоні, визначити недоліки та розробити заходи покращення діагностичного алгоритму.

Матеріали і методи. Проведено ретроспективний аналіз медичної документації 64 пацієнтів, прооперованих на базі клінічної лікарні Кривого Рогу з приводу ПГПТ. Проаналізовано анамнез та клінічні прояви захворювання, результати додаткових обстежень (УЗД, лабораторні дослідження крові і сечі, рентгенологічні данні кісткового каркасу), результати хірургічного лікування.

Результати досліджень та їх обговорення. Серед оперованих пацієнтів більшість склали 59 жінок (92,2 \%) віком від 37 до 80 років, з перевагою вікової категорії від 40 до 60 років - $64 \%$. При аналізі анамнезу захворювання встановлено, що у 21 (32,9 \%) пацієнта ПГПТ діагностовано при обстеженні з приводу патології щитоподібної залози (ЩЗ), а у 43 (67,1 \%) - 3 приводу його вісцеропатичних проявів (жовчнокам'яна і сечокам'яна хвороби, переломи кісткового каркасу, виразкова шлунково-кишкова кровотеча).

У діагностиці ПГПТ на фоні патології ЩЗ, особливо багатовузлового зоба, важливу роль ві- 
діграла ультразвукова діагностика експертного рівня (УЗД) з визначенням мультипараметричних показників. У 15 (71,4 \%) пацієнтів наявність патологічних змін прищитоподібних залоз (ПЩЗ) визначено тільки при повторному УЗД у спеціалізованому центрі. Тільки у 6 (28,6 \%) пацієнтів вказаної групи патологію ПщЗ запідозрили на первинному етапі УЗД скринінгового рівня за умови досить великих розмірів аденоми ПЩЗ та моновузлового ураження ЩЗ.

У 43 (67,1 \%) пацієнтів з вісцеропатичними клінічними проявами ПГПТ його наявність встановлено при додатковому цілеспрямованому обстеженні, яке частіше проводили в стаціонарних відділеннях клінічної лікарні при їх госпіталізації з приводу ускладнень захворювання: гострий калькульозний холецистит, ниркова або печінкова коліки, переломи кісток, зубо-щелепні хвороби). Приводом такого факту стало регулярне проведення кафедрою хірургії, ортопедії і травматології ФПО ДМА тематичних інформаційниї лекцій і конференцій для лікарів клінічної бази з питань діагностики ПГПТ та впровадження листків-опитування пацієнтів із підозрою на ПГПТ.

Серед 21 пацієнта, де ПГПТ діагностовано на фоні патології ЩЗ, переважали ниркова і змішані (нирково-абдомінальна) форми - відповідно, 11 (52,4 \%) і 7 (33,3 \%); ще у 3 (14,3 \%) - кісткова форма ПГПТ. При цьому їх прояви були малосимптомними або безсимптомними. Приводом для встановлення діагнозу ПГПТ стали дані УЗД та їх лабораторне підтвердження.

У 43 хворих з маніфестними проявами ПГПТ більшість склали пацієнти зі змішаною формою 27 (63 \%): кістково-ниркова - 11 (40,7 \%); нирково-абдомінальна (MKX+CKX) - 8 (29,6 \%); кістково-абдомінально-ниркова - 5 (18,5 \%); 3 (11,2 \%) - нирково-абдомінально-судинна. Виявилось, що маніфестними проявами ПГПТ найчастіше проявлялись ураженнями кісткового каркасу (патологічні переломи кінцівок, хребта, остеопороз із вираженим больовим синдромом), нирок (CKX 3 частими нирковими коліками та коралоподібними конкрементами) та гепатобіліарнодуоденальної зони (ЖКХ з холедохолітіазом, виразкова хвороба ДПК з кровотечами та частими рецидивами, хронічний біліарний панкреатит).

На жаль, більшість хворих із ПГПТ госпіталізована 3 маніфестними ускладненнями захворювання, які розвивалися поступово, протягом тривалого часу і могли бути розпізнані раніше за умови застосування комплексного діагностичного алгоритму та настороги лікарів первинної ділянки. Особливо демонстративною маніфестацією ПГПТ є його кісткова форма, якій часто переду- ють інші прояви та які не завжди враховують лікарі суміжних спеціальностей. Клінічні приклади підтверджують цей месенджер.

Хвора П., 40 років, домогосподарка, госпіталізована 15.08.2015 р. в травматологічне відділення клінічної лікарні з приводу консолідуючого перелому лівого стегна та свіжого перелому правого. Із анамнезу встановлено, що за 7 днів до госпіталізації при незначному фізичному навантаженні (потягування у ліжку) відчула хрускіт у ділянці лівого стегна і появу болю при зміні його положення. За медичною допомогою не зверталась. У день госпіталізації після подібного навантаження відчула біль у ділянці правого стегна з вираженим порушенням його функції. Бригадою ШМД доставлена на травмпункт клінічної лікарні, після рентгенологічного підтвердження переломів шийки лівого (рис. 1) і правого (рис. 2) стегна і вираженого остеопорозу кісток лівої гомілки (рис. 3), госпіталізована. При опитуванні було встановлено, що з 25 років у пацієнтки наявні часті напади ниркової коліки на тлі наявності конкрементів в обох нирках; у 30 років виражена крихкість і випадання зубів; близько 3 років тому в ділянці верхньої щелепи та лівої ключиці поява пухлиноподібного неболючого утворення (рис. 4), протягом останнього року незначна хронічна анемія. Амбулаторно лікувалася і спостерігалася в уролога, стоматолога, сімейного лікаря. Обстеження кальцемії, рівня паратгормону не проводили. Після консультації співробітниками кафедри хірургії, травматології та ортопедії ФПО було встановлено наявність патологічних переломів обох

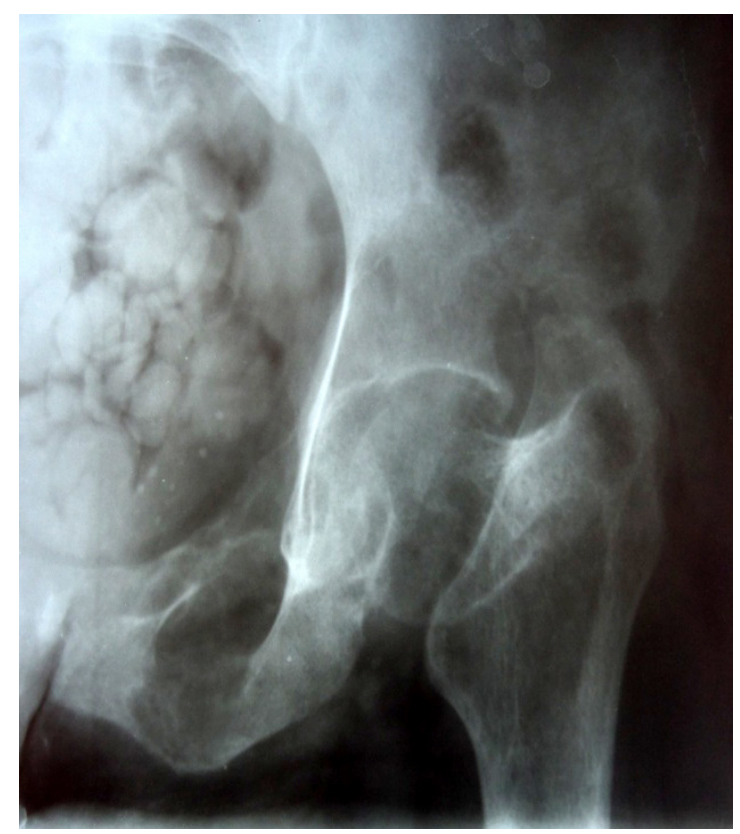

Рис. 1. Перелом лівого стегна. 


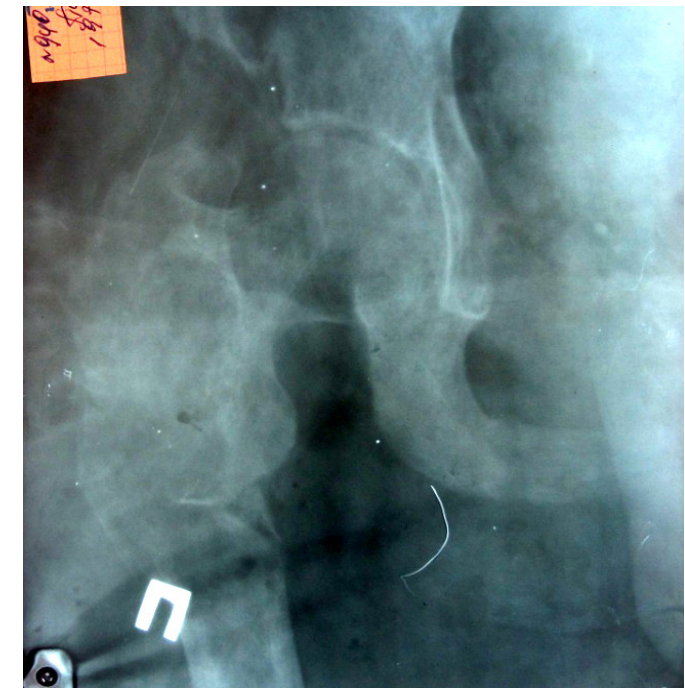

Рис. 2. Перелом правого стегна.

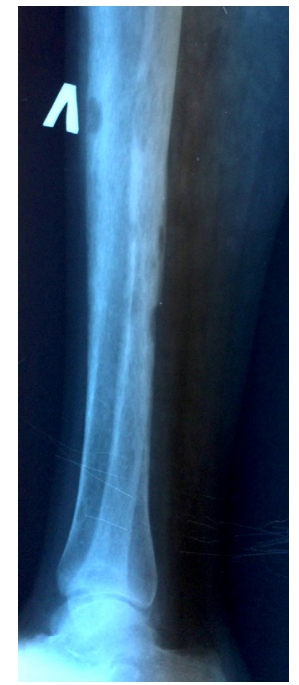

Рис. 3. Виражений остеопороз кісток лівої гомілки. стегон і додатково призначено діагностичний алгоритм за ПГПТ. При УЗД ЩЗ було виявлено вузлове ураження лівої частки ЩЗ та наявність аденоми ПЩЗ зліва (рис. 5). Лабораторне дослідження крові підтвердило еутиреоїдний стан, наявність гіперкальцемії (Ca ${ }^{++}=3,2$ ммоль/л, при нормі 1,16-1,32), значне підвищення рівня паратгормону (1742 пкг/мл, при нормі 9,5-75), анемічний синдром (гемоглобін 100г/л). Після передопераційної підготовки 09.09.15 р. виконано хірургічне втручання в обсязі екстрафасціальної гемітиреоїдектомії зліва та паратиреоїдектомії зліва аденоматозно зміненої верхньої ПЩЗ (рис. 6). При патогісто-

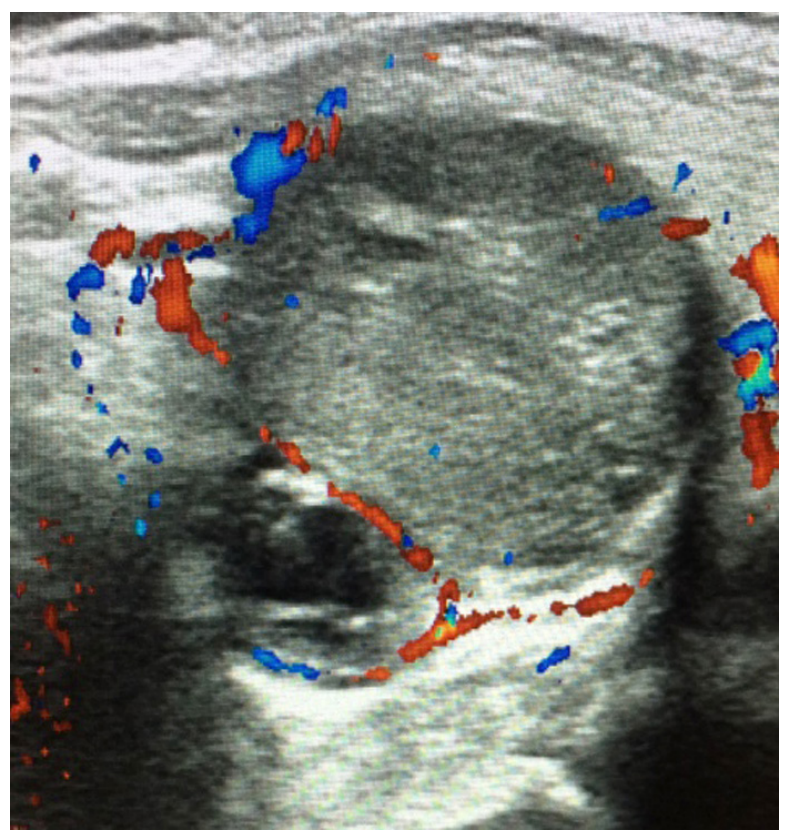

Рис. 5. Вузол лівої частки ЩЗ та аденома ПщЗ. логічному дослідженні встановлено фолікулярну аденому ЩЗ та аденому ПЩЗ. Контрольний рівень паратгормону 11.09.15. p. - 20 пкг/л. Пацієнтку виписали на амбулаторне лікування 16.09.15. p. у задовільному стані.

Хвора Б., 57 років, госпіталізована у клініку 24.05.2013. з приводу псевдосуглоба лівого плеча, довготривалого консолідуючого перелому правого стегна, ускладненого контрактурою (рис. 7-9). Із анамнезу встановлено, що пацієнтка з 40 річного віку страждає від сечокам'яної хвороби з періодичними нападами ниркової коліки, в зв'язку $з$ чим спостерігається в уролога. У 2003 р. прооперована з приводу гострого калькульозного холециститу. 32012 р. прогресування загальної слабкості, пригнічення настрою. Цього ж року при незначній травмі зазнала перелому лівого плеча,

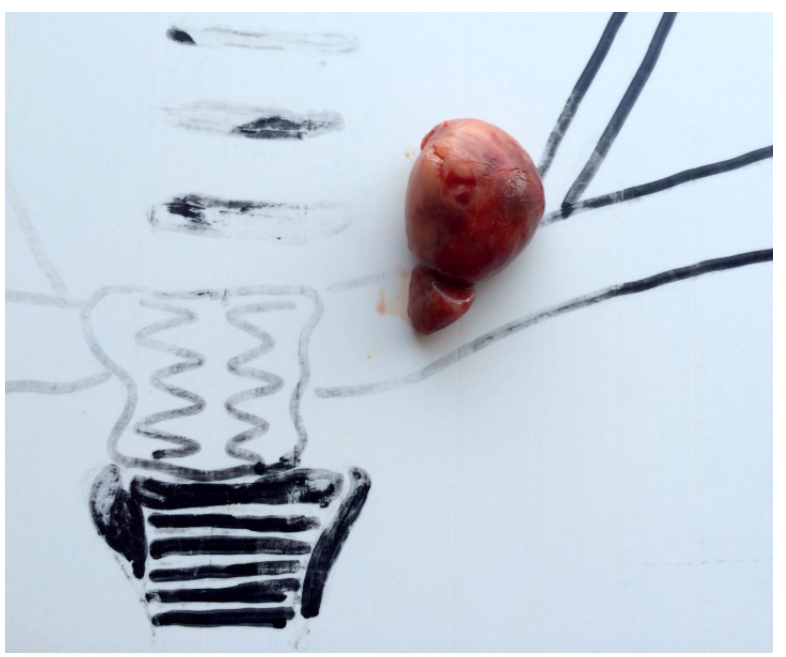

Рис. 6. Аденома ПщЗ. 


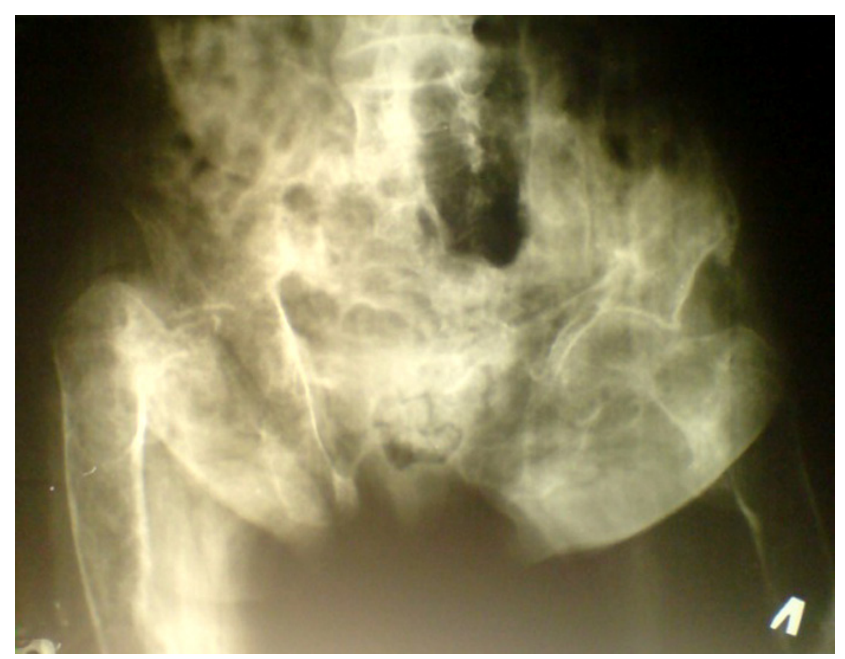

Рис. 7. Рентгенограма тривалого консолідуючого перелому правого стегна.

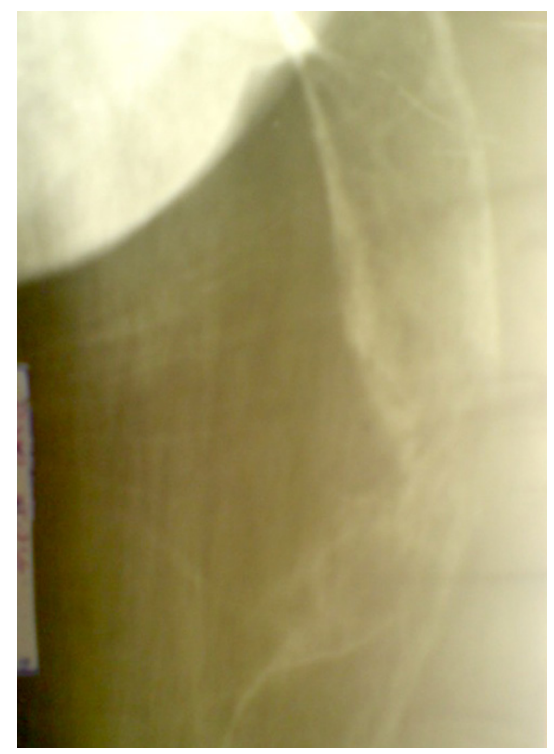

Рис. 8. Рентгенограма псевдосуглоба лівого плеча.

наслідком якого стало формування псевдосуглоба. На фоні післятравматичної депресії була спроба суїциду. У 2013 р. при падінні внаслідок слабкості в кінцівках у хворої стався закритий перелом правого стегна із значною затримкою консолідації та формуванням контрактури. Після консультації на кафедрі хірургії, травматології та ортопедії госпіталізована. Після виконання додаткового обстеження діагностовано наявність ПГПТ на тлі аденоми лівої верхньої ПщЗ до 3 см в діаметрі (рис. 9). При лабораторному дослідженні рівень ПГ=1056 пкг/мл, Са ${ }^{++}=2,53$ ммоль/л. 05.06.13. p. виконано хірургічне лікування в обсязі видалення аденоматозно збільшеної ПЩЗ (рис. 9). Гістологічний висновок: світлоклітинна аденома ПЩЗ (рис. 10). Контрольний рівень ПГ 08.06.13. р. 10 пкг/мл. На 7-му добу пацієнтку переведено до
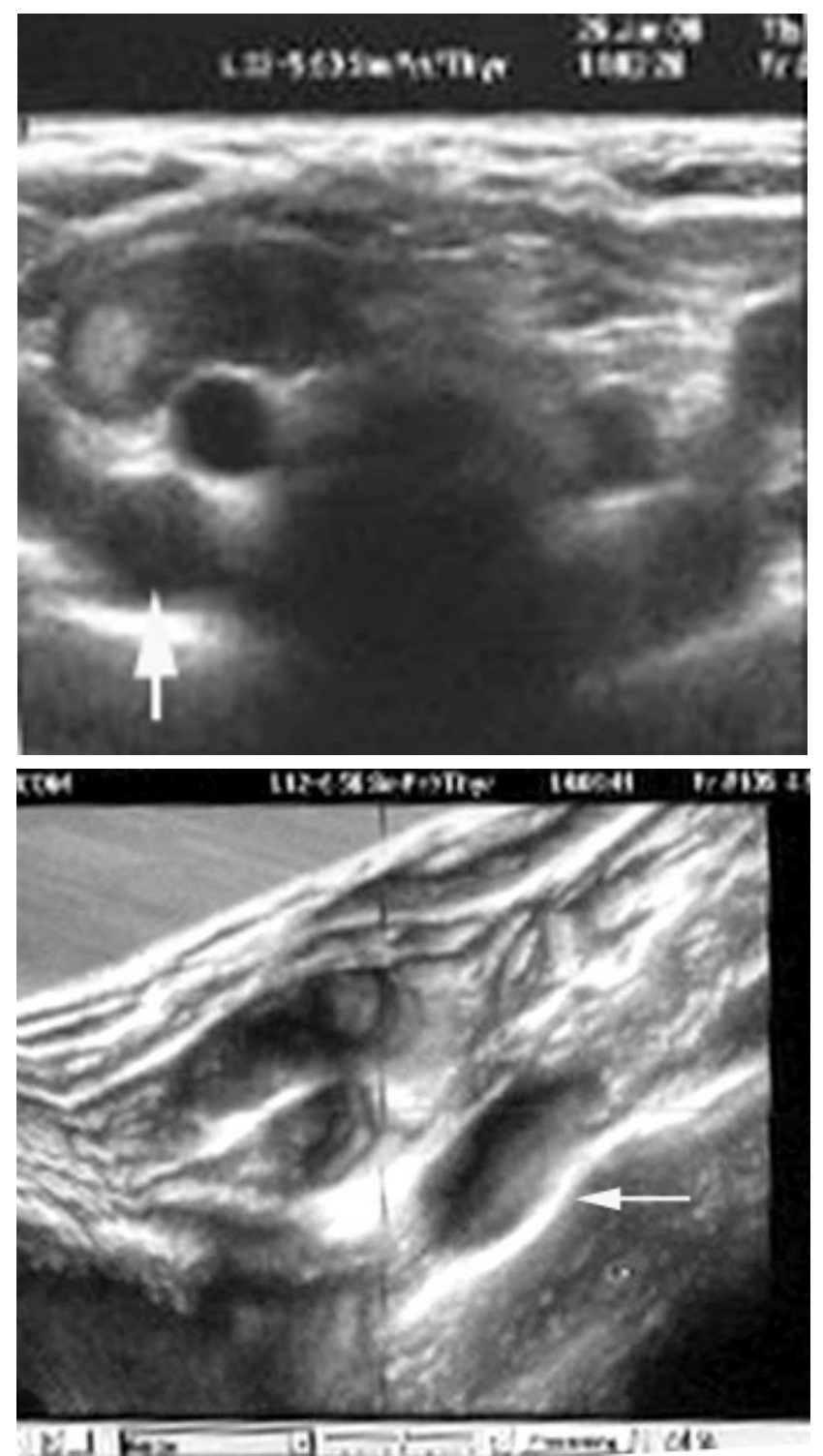

Рис. 9. Сонограма аденоми Пщз.

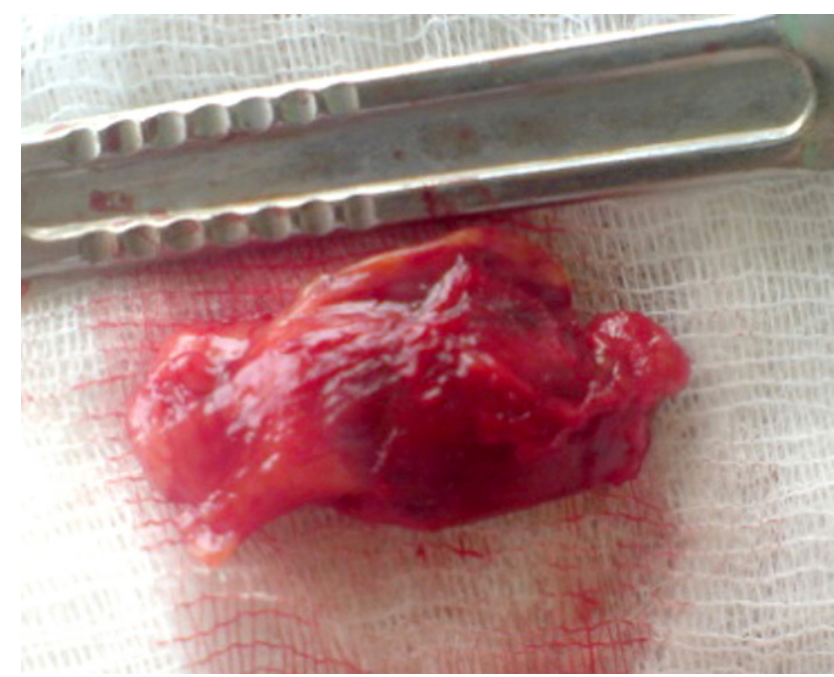

Рис. 10. Видалена аденома Пщз. 
травматологічного відділення для подальшого лікування кісткової патології.

Обидва клінічні приклади демонструють проблему пізньої діагностики ПГПТ навіть при його маніфестних формах.

Висновки. 1. Хірургічне лікування ПГПТ в більшості випадків виконують при його маніфестних формах, коли формуються інвалідизуючі ускладнення. Найчастіше маніфестними проявами ПГПТ є змішані форми з перевагою уражень кісткового каркасу та нирок.

\section{СПИСОК ЛІТЕРАТУРИ}

1. Хирургическая эндокринология: руководство / Под ред. А. П. Калинина, Н. А. Майстренко, П. С. Ветшева. - СПб. : Питер, 2004. - 960 с.

2. Черенько С. М. Первичный гиперпаратиреоз: основы патогенеза, диагностики и хирургического лечения: монография / С. М. Черенько. - Киев, 2011. - 148 с.

3. Романчишен А.Ф. Хирургия щитовидной и околощитовидных желез / А. Ф. Романчишен. - СПб. : ИПК “Вести”, 2009. - 647 с.

4. Панькив В. И. Гиперпаратиреоз: диагностика, клинические признаки и симптомы, современные подходы к лечению / В. И. Панькив // Міжнародний ендокринологічний журнал. № 1, 49. - 2013. - С. 87-98.

5. Методы визуализации околощитовидных желез и парати-

\section{REFERENCES}

1. Kalinina, A.P. Maystrenko, N.A. \& Vetsheva, P.S. (Eds.). (2004). Khirurgicheskaya endokrinologiya: rukovodstvo [Surgical endocrinology: guidance]. St. Petersburg: Peter [in Russian].

2. Cherenko, S.M. (2011). Pervichnyy giperparatireoz: osnovy patogeneza, diagnostiki i khirurgicheskogo lecheniya: monografiya: monografiya [Primary hyperparathyroidism: the fundamentals of pathogenesis, diagnosis and surgical treatment: monograph]. Kiev [in Russian].

3. Romanchyshen, A.F. (2009). Khirurgiya shchitividnoy $i$ okoloshchitovidnykh zhelez. [Surgery of the thyroid and parathyroid glands]. St. Petersburg: IPK "Vesti” [in Russian].

4. Pankiv, V.I. (2013). Giperparatireoz: diagnostika, klinicheskie priznaki i simptomy, sovremennye podkhody k lecheniyu [Hyperparathyroidism: diagnosis, clinical signs and symptoms, modern approaches to treatment]. Mizhnarodnyi endokrynolohichnyi zhurnal - International Endocrinological Journal, (149), 87-98 [in Russian].

5. Kalinin, A.P., Pavlov, A.V., \& Aleksandrov, Yu.K. (2010).
2. Сьогодення потребує негайного визначення “проблемних” за ПГПТ захворювань та включення у стандарти їх діагностики скринінгових маркерів: рівень іонізованого кальцію крові, паратгормону та УЗД ЩЗ. При виявлені їх патологічних змін - консультація хірурга-ендокринолога.

3. Необхідно підвищити рівень обізнаності лікарів первинної ланки у питаннях клінічних проявів ПГПТ та його ускладнень з метою покращення раннього виявлення і своєчасного хірургічного лікування.

реоидная хирургия: руководство для врачей / А. П. Калинин, А. В. Павлов, Ю. К. Александров и др. - Видар, 2010.

6. Стандарти діагностики та лікування ендокринних захворювань / За ред. член.-кор. НАН та АМН України, проф. М. Д. Тронька // Довідник "VADEMECUM info ДОКТОР Ендокринолог”. - К. : ТОВ “ГІРА “Здоров’я України”, 2005. - 312 с. - (Серія “Бібліотека “Здоров’я України”).

7. Зубкова С. Т. Сердечно-сосудистые заболевания при заболеваниях паращитовидных желез / С. Т. Зубкова // Здоров’я України. Діабетологія. Тиреодологія. Метаболічні розлади. Київ. - 2014. - № 1. - С. 56-57.

8. Нечай О. П. Труднощі встановлення діагнозу первинного гіперпаратиреозу [Текст] / О. П. Нечай // Український журнал дитячої ендокринології. - 2015. - № 3/4. - С. 82-86.

Metody vizualizatsii okoloshchitovidnykh zhelez i paratireoidnaya khirurgiya: rukovodtsvo dlya vrachey [Methods for visualization of parathyroid glands and parathyroid surgery: a guide for physicians]. Vidar [in Russian].

6. Tronko, M.D. (2005). Standarty diahnostyky ta likuvannia endokrynnykh zakhvoriuvan [The standard of diagnosis and treatment of endocrine diseases]. Kyiv: TOV "HIRA" Zdorovia Ukrainy [in Ukrainian].

7. Zubkova, S.T. (2014). Serdechno-sosudistye zabolevaniya pri zabolevaniy parashchitovidnykh zhelez [Cardiovascular diseases in parathyroid gland diseases]. Zdorovia Ukrainy. Diabetolohiia. Tyreodolohiia. Metabolichni rozlady - Health of Ukraine. Diabetology. Thyroidology. Metabolic Disorders [in Russian].

8. Nechai, O.P. (2015). Trudnoshchi vstanovlennia diahnozu pervynnoho hiperparatyreozu [Difficulties in diagnosing of primary hyperparathyroidism]. Ukrainskyi zhurnal dytiachoi endokrynolohii - Ukrainian Journal of Pediatric Endocrinology, (3/4), 82-86 [in Ukrainian]. 


\title{
V. I. DESIATERYK, S. P. MIKHNO, L. M. POLISCHUK, O. V. ZALOZNYI
}

Dnipropetrovsk Medical Academy

Kryvyi Rih City Clinical Hospital № 2 of Dnipropetrovsk Regional Counsil

\section{PROBLEMS OF DIFFERENT DIAGNOSTICS OF THE PRIMARY HYPERPARATHYREOSIS}

The aim of the work: to study the timeliness and quality of diagnosis of primary hyperparathyroidism (PHPT) in the region, to identify deficiencies and to develop measures to improve the diagnostic algorithm.

Materials and Methods. A retrospective analysis of the medical records of 64 patients operated on the basis of the Kryvyi Rih Clinical Hospital on PHPT was conducted. The anamnesis and clinical manifestations of the disease, results of additional examinations (ultrasound, laboratory blood and urine tests, X-ray data of the bone carcass), results of surgical treatment were analyzed.

Results and Discussion. The paper presents a retrospective analysis of diagnostic efficacy in 64 patients operated for primary hyperparathyroidism (PHPT). Malosymptomatic or asymptomatic forms of PHPT were detected in $32.9 \%$ of patients with thyroid gland pathology (thyroid gland). In 43 (67.1\%) patients with visceropathic clinical manifestations of PHPT, its presence was established with additional targeted screening, which was more often conducted in the hospital departments of a clinical hospital during their hospitalization due to complications of the disease. Surgical treatment of PHPT in most cases is performed in manifested its forms, when the formation of invalidating complications. The most frequent manifestations of PHPT are mixed forms with the predominance of bone marrow and kidney lesions. The clinical cases of patients with a delayed diagnosis of manifested forms of PHPT are presented. It is noted that the reason for this provision is the low level of primary link doctors' knowledge and adjacent specialties in the questions of PHPT diagnostics.

Key words: primary hyperparathyroidism; manifest form; deficiencies of diagnosis.

\section{В. И. ДЕСЯТЕРИК, С. П. МИХНО, Л. Н. ПОЛИЩУК, А. В. ЗАЛОЗНЫЙ}

Днепропетровская медицинская академия МЗ Украины

Криворожская городская клиническая больница № 2 Днепропетровского областного совета

\section{ПРРОБЛЕМЫ ПОЗДНЕЙ ДИАГНОСТИКИ ПЕРВИЧНОГО ГИПЕРПАРАТИРЕОЗА}

\begin{abstract}
Цель работы: изучить своевременность и качество диагностики первичного гиперпаратиреоза (ПГПТ) в регионе, определить недостатки и разработать меры улучшения диагностического алгоритма.

Материалы и методы. Проведен ретроспективный анализ медицинской документации 64 пациентов, перенесших операцию на базе клинической больницы Кривого Рога по поводу ПГПТ. Проанализированы анамнез и клинические проявления заболевания, результаты дополнительных обследований (УЗИ, лабораторные исследования крови и мочи, рентгенологические данные костного каркаса), результаты хирургического лечения.

Результаты исследований и их обсуждение. В работе представлен ретроспективный анализ эффективности диагностики у 64 пациентов оперированных по поводу первичного гиперпаратиреоза. У 32,9 \% пациентов с патологией щитовидной железы (ЩЖ) выявлено малосимптомные или бессимптомные формы ПГПТ. У 67,1 \% пациентов с висцеропатическими клиническими проявлениями ПГПТ его наличие установлено при дополнительном целенаправленном обследовании, которое чаще проводилось в стационарных отделениях клинической больницы при их госпитализации по поводу осложнений заболевания. Хирургическое лечение ПГПТ в большинстве случаев выполняется при манифестных его формах, когда формируются инвалидизирующие осложнения. Наиболее частыми манифестными проявлениями ПГПТ являются смешанные формы с преобладанием поражений костного каркаса и почек. Приведены клинические случаи пациентов с запоздалой диагностикой манифестных форм ПГПТ. Отмечено, что причиной такого положения является низкий уровень осведомленности врачей первичного звена и смежных специальностей в вопросах диагностики ПГПТ.
\end{abstract}

Ключевые слова: первичный гиперпаратиреоз; манифестная форма; недостатки диагностики. 